\title{
The Effect of Applying Cooperative Integrated Reading and Composition (CIR ) Technique on Students' Achievement in Writing Recount Text
}

\author{
Sara Frimaulia $^{1}$, Edi Suprayetno ${ }^{2}$ \\ STKIP Al Maksum ${ }^{1}$, APP - APIPSU Medan ${ }^{2}$ \\ frimauliasara@yahoo.com ${ }^{l}$ \\ edisuprayetno@gmail.com ${ }^{2}$
}

\begin{abstract}
This study aims to discover the effect of applying Cooperative Integrated Reading and Composition (CIRC) Technique on Student's Achievement in writing Recount Text. It was conducted by using experimental research design. This population was the 80 students of SMP Negeri 1 Stabat as Sample. The samples of the research were two classes divided into two groups, experimental and control group which were chosen by using random sampling technique. The Grade VIII-B as Experimental Group was taught by using Cooperative Integrated Reading and Composition and grade VIII-A as control group was taught by using conventional teaching writing. The instrument used to collect the data was by asking the students to write a Recount text. Based on the result of the data analysis, it was concluded that using Cooperative Integrated Reading and Composition significantly affect the student's ability in writing recount text ( $\mathrm{t}$-calculated $>\mathrm{t}$-table, $\mathrm{p}=0.05$ ). The using CIRC made the students write recount text grammatically that without using CIRC. The calculation of t-test is $2.38>1.67$ with df 78 and the level of significance 0.05 . It means that the using CIRC has significant effect on writing recount text.
\end{abstract}

\section{Keywords: Experimental Research, Cooperative Integrated Reading And Composition (CIRC) Technique, Writing Achievement, Recount Text.}

\section{The Background of The Study}

Writing is one of the four basic skills in learning English as a foreign language. Writing is an important communication tool. Writing is a way of conveying ideas, opinion and thoughts and expressing them as a series of words and writing them down in a piece of paper. Actually writing is an opportunity, it allows students to express something about themselves, explore and explains ideas. Students can convey their ideas in their mind by organizing them into a good text so that the others know them and they can think critically. Unfortunately, Indonesian students'writing in English is still low. The students are not able to write English well, they don't use appropriate words and grammar in writing.

According to Competence Based Curriculum, writing is one four skills that should be mastered by students. They should be able to write in English writing is one four basic language skills is difficult to study. It is stated by Allan and Vallet $(1981 ; 5)$ who say that writing maybe considered as the most of difficult 
language skills. Hornby(1974;1016) say that writing is "to put down by means of word on paper". Expressing the ideas and thought should be known by the students since it becomes the goal of writing. On the other hand the students should be able to express their ideas or opinions in paragraph form.

In this study, the writer deals with writing as her topic because during her teaching practice (PPL) at SMP, she observed that most of the students are not able to write successfully. The writer found that the students are not able to write in simple sentence especially in writing recount text. They are not confident to use their own English, because of their limited mastery on grammar and vocabulary, and they are not able to organize their ideas into a good text. Moreover, in writing process, the students have to master the knowledge not only about the material but also about grammar and vocabulary. it is needed to know some methods for helping students in writing ability. The appropriate and comprehensive method for teaching writing is Cooperative Integrated Reading and Composition (CIRC). CIRC is derived from cooperative learning which facilities the students to understand the text or passage given. The students are taught to work together with their friends. They work together to achieve the goal or the success which has always been desired by them. It will help the students in the writing recount text.The research question "Is there any significant effect on students' achievement in writing recount by Cooperative Integrated Reading and Composition technique"?

\section{The Conceptual Framework}

Writing is one of the most important skills in language learning besides reading, listening and speaking. In writing, the students must understand the text and passage. Writing is a process of communication that introduces graphic symbol or codes in order to convey the message to the readers. It is also result of combining graphic symbol such as words, phrases and sentences later on formed become paragraph.

Cooperative Integrated reading and Composition (CIRC) is comprehensive method for teaching reading, writing and languages arts in the upper elementary grades and middle grades. CIRC consists of three principle elements: story related activities, direct instruction in reading comprehension and language and art and writing. In all of these activities, students work in heterogeneous learning teams. The activity in CIRC involves teacher presentation, team practice, independent practice, assessment and testing. The major components of CIRC are Reading Groups, Teams, Story related writing, Partner Checking, Test, and Language Arts and Writing. CIRC is considered to be the most effective way of teaching writing ability.

In this applying, the CIRC create comfortable writing learning condition. All major components of CIRC involve many activities such as Reading Groups, Teams, Story related writing, Partner Checking, Test, and language Arts and Writing make the students enjoy the activities because the students can read the text and correct any errors that the students may make. After that they can identify the story grammar (the character, the setting, the problem and the solution in the story). And then, in teams, the students can summarize the main point about the story and make draft composition about ideas and organizational plan and revise of their composition. Individually, the students can write the words and meaning sentences from the list of vocabularies given them and write into recount text. They achieve greater success because they can workand compete in team as well as individually work and they are a part of the teaching learning process.

\section{Research Design}

This research was conducted in experimental design which consists of pre-test and post-test in order to know the effect of applying cooperative integrated reading and composition (CIRC) on students' achievement in writing recount text.

In conducting the experimental research, the sample was divided into two groups. They are control group, which was taught by using conventional method in writing and the experimental group, which was taught by applying Cooperative Integrated Reading and Composition. 


\section{Population and Sample}

The population of this study were class VIII SMP N 1 Stabat. There were eight parallel classes. The total number of the VIII students are 316 students. This research used to random sampling technique. The sample was taken two classes from eight class using lottery, the class which taken first was the experimetal group while next class was control group. Therefore, the sample of this research was class VIII-B as the experimental group, while class VIII-A as control group taken to represent the entire population.

\section{The Instrument of Collecting Data}

This research used writing test as an instrument to collect the data. First for experimental and control group, the student was given pre-test to find out the homogeneity of the sample and to know the mean on scores of both groups. And after writer gave treatmentwith the same contents, posttest was given again to experimental and control group to know the effect of CIRC technique in the experimental class.

\section{The Procedure of Research}

\section{Pre-test}

Pre- test was conducted to find out the mean scores of each group, the experimental and the control group. Both experimental and control group test before they taught about recount paragraph. Writer asked them to write a simple recount paragraph with topic given by the writer.

\section{Treatment}

Treatment was given to the experimental group for some period of time. The experimental group students were taught how to write a short paragraph by using Cooperative Integrated and reading Composition. While, the control group was taught by using conventional method.

Conventional method in this study means the common method used by the English teachers, as it was indicated by the researcher in the classroom. It is very common phenomena while the teacher would teach or enlarge the students, they just ask their students to write a paragraph by using a correct grammar and construct a meaningful utterance, without teach the effective way how to make a short paragraph and construct a grammatical rules.

Conventional method does not recognize the collaboration process (the teaching-learning process can be taught through any technique, such as: exploration, explanation and expression).

Table1. Treatment for Experimental group.

\begin{tabular}{|c|c|c|}
\hline Meetings & Activities & Times \\
\hline 1 & $\begin{array}{l}\text { 1. Teacher greeted the students to open the class } \\
\text { 2. Give Pre-test }\end{array}$ & $\begin{array}{l}5 \text { minutes } \\
35 \text { minutes }\end{array}$ \\
\hline 2 & $\begin{array}{l}\text { Reading groups } \\
\text { The teacher divided the student into some groups } \\
\text { Team } \\
\text { The students then divided into several teams. A teams consist of } 4-5 \text { students, } \\
\text { two students from high reading group and two students from low reading group. } \\
\text { Story-Related Writing } \\
\text { The teacher will introduces and discussed the text or story to the writing } \\
\text { groups. Then the teacher distribute the story text to all teams. } \\
\text { Partner Reading } \\
\text { The teacher guided the students in teams to read the write the story with their } \\
\text { partner, alternating each paragraph. The partenr corrects any error the writers } \\
\text { may take. }\end{array}$ & 15 minutes \\
\hline 3 & Story grammar and story related writing & 15 minutes \\
\hline
\end{tabular}


The students are given question realted the story, that emphasize the story grammars. Then the students identify the characters, the setting, the problem in the story and the solution the story. At the end, the students responds the story

And write a few parargraph related the topic.

15 minutes

Words out loud

The students given a list of new words used in the story. The students learn the word, and write the words in their words correctly.

5 minutes

Word meaning

After students practice their pronunciation of the word in the list of vocabulary, they are asked to look for the meaning in the dictionary, then the student wrote the meaning sentences of the words.

$4 \quad$ Partner Checking

After student completed the activities above, their partners intial the student wrote assignment form indicating that they have completed the story. Then they ask to their partner in team check it.

Test

Students are given a comprehension test on the story, asked to wrote meaningful sentences for each vocabulary word. Students are not permitted to help another on this test.

Integrated language and arts

The students wrote assignment draft composition about ideas and organizational plan, then they work with teammates to revise the contents of their composition, and emphasizing the form of grammatical and mechanical correctness.

5 1. Gave direction related to the Post test

5 mniutes

2. Gave post test

10 mniutes

15 minutes

15 minutes

35 minutes

In control group, the students were taught by applying conventional method. The students are always asked to open their English book in getting some information about the recount writing. The teaching procedures in control group can be seen in Table 2 .

Table 2 Teaching Procedures in Control Group

\begin{tabular}{|c|c|c|}
\hline Meeting & Activities & Times \\
\hline 1 & 1. Teacher greeted the students to open the class & 5 minutes \\
\hline \multirow[t]{2}{*}{2} & $\begin{array}{l}\text { 2. Gave Pre-test } \\
\text { 1. The teacher introduced the topic to students }\end{array}$ & 15 minutes \\
\hline & 2. The teacher asked them to write and found the difficult words & 25 minutes \\
\hline \multirow[t]{2}{*}{3} & $\begin{array}{l}\text { 1. The teacher discussed the story with the students, asked them to } \\
\text { translate the text and wrote what the text about }\end{array}$ & 15 minutes \\
\hline & 2. The teacher translate the text, give example of correct vocabulary & 25 minutes \\
\hline \multirow[t]{2}{*}{4} & $\begin{array}{l}\text { 1. The teacher asked the students practiced and wrote their vocabulary } \\
\text { based on teacher instruction } \\
\text { 2. The teacher explained what the story was about and then asked them } \\
\text { to do exercise, to answer the question based on the text }\end{array}$ & 5 minutes \\
\hline & & 35 minutes \\
\hline 5 & $\begin{array}{l}\text { 1. Give direction related to the Post test } \\
\text { 2. Give Post-test }\end{array}$ & $\begin{array}{l}5 \text { minutes } \\
35 \text { minutes }\end{array}$ \\
\hline
\end{tabular}

\section{Post-Test}

The post-test was administered after the treatments have been completed. The administration of this test is meant to find out the difference in mean scores of both the control and experimental group. This posttest was used to know the effect of Cooperative Integrated and Reading Comparison on the experimental group. Reliability of The Test 
Brown (1988:154) says that reliability is the test designed as the extent to which the result can be considered consistent or stable. In this study, Pearson Product Moment is used to know the reliability of the the whole test whether reliable or not.

The Technique for Analyzing Data

To prove the hypothesis it is needed to analyze the data by applying the t-test for independent sample.

\section{DataAnalysis and Research Findings}

The data was obtained by giving the essay test to students in order to know their achievement in writing recount text. It is calculated by using the scores of writing test in both of experimental and control groups. The analysis is intended to get the significant difference between using Cooperative Integrated Reading and Composition and without using Cooperative Integrated Reading and Composition in writing recount text. The analyzing of the data through pre -test and post-test in both groups, experimental and control groups are computed by applying t-test formula to proof the hypothesis in this study.

From the data which had been collected, the highest and the lowest pre-test score in the experimental class and Control Class as a following table 3

Table 3 The Score of experimental class and Control Class

\begin{tabular}{ccc} 
& Experimental Class & Control Class \\
\hline Pre-test & 53,7 & 55,27 \\
Post-test & 81,52 & 71,8 \\
\hline
\end{tabular}

The mean score of both groups were significantly different, namely 71.8 for control group and 81.52 for experimental group. It means that the students who had using Cooperative Reading Integrated and composition got better results in writing recount text than those who had not.

\section{The Reliability of the Test}

Collecting data, researcher had administered the same test for both two groups, experimental and control groups.To know whether the test is reliable or not, the researcher used Person Product Momment formula.

The calculation shows that reliability of the test was 0.70. Based on the Aruan (2007:34) category of reliability of test $0.60 \leq \mathrm{r} \leq 0.80$ was high reliability, so 0.70 was a high reliability.

Testing Hypothesis

The hypothesis is aimed at knowing the wheteher the hypothesis is accepted or rejected. Ha (Alternative hypothesis is accepted if t-observed $>\mathrm{t}$ - table. Because Null Hypotheses (Ho) had been successfully rejected with the value $\mathrm{t}_{\mathrm{o}}$ (2.38) exceeded the value of $\mathrm{t}$-table (1.67) with $\alpha=0.05$ and $\mathrm{df}=78$ (see Appendix $\mathrm{C}$ )

$\mathrm{t}$-0bs $>\mathrm{t}$-table $(\alpha=0,05)$ wit df:40

$3.38>1,67(\alpha=0.05)$ wit df:40

This result showed that Ha was accepted and Ho was rejected.

\section{Research Findings}

After analyzing of the data,the researcher found that using Cooperative Integrated Reading and Composition gives a significant effect to students' achievement in writing recount text. It was found that the mean of experimental group (81.52) was higher than the mean of control group (71.8). It is proved by result of t-test in which the score of t-calculated is higher than t-table (t-observed $2.38>\mathrm{t}$-table 1.67 with $\mathrm{df} 40$ at level significance 0.05 ). So hypothesis is accepted. 


\section{Conclussion}

Based on the result of the data analysis, it was concluded that using Cooperative Integrated Reading and Composition significantly affect the student's ability in writing recount text ( $\mathrm{t}$-calculated $>\mathrm{t}$ table, $\mathrm{p}=0.05$ ). The using CIRC made the students write recount text grammatically that without using CIRC.The calculation of t-test is $2.38>1.67$ with $\mathrm{df} 78$ and the level of significance 0.05 . It means that the using CIRC has significant effect on writing recount text. From the result of the data, it can be seen that the highest score of experimental group was 96 and the lowest score was 64 in post-test. Meanwhile the highest score of control group was 91 and the lowest score was 55 in post-test.

\section{References}

Allan and Vallete, Ann.1976. Teaching English as a Second Language. A book of writing, New delhi:Mcgaw Hill Publishing Company.

Ary, Donald. 2002. Introduction to Research in Education. Singapore: Wardswith.

Bloom, B,S. 1996. Taxonomy of Educational Objectives: the Classification of educational Goals. New York; Longman.

Brown, H. Douglas. 2001 Teaching By Principle: An Interactive Approach to Language Pedagogy. (2 ${ }^{\text {nd }}$ ed). San Francisco: Addison Wesley Longman.

Clark and Clark. 1997. Physicology and Language. USA.Harcourt Brace Jovanovich.

Durukan, Erhan.2010. effect of Cooperative Integrated Reading and Composition(CIRC) Technique on Reading-Writing Skills (pp.102-109). Turkey: Black Sea Technical University

Gerrot,L.\&Wignell, P. 1994. Making Sense of Functional Grammar.Cammeray: Antipodean Educational Enterprises.

Harmer, J.2004.How to Teach Writing. London: Longman.

Harmer, J. 2001.The Practice of English Language Teaching (Third Edition: Completely Revised and Updated). England:Longman.

Hoglas, A.And Jacob. 2002. Testing for Language Teacher, $2^{\text {nd }}$ Ed. Cambridge:

Cambridge University Press.

Hyland, K.2003.Second Language Writing. New York: Cambridge University Press.

Hyland, K.2002. Teaching and Researching Writing. Great Britain: Longman.

Istarani, 2012.58 Model PembelajaranInovatif.Medan : Media Persada

Published by English Lecturers and Teachers Association (ELTA)

Copyright (C) 2021, authors 
Juita, Mahdum,Safri.2013. The application of Circ technique to improve the ability of the second year students of SMPN.14 Pekanbaru in Comprehending Descriptive Text.PekanBaru

Karrie,Jones\&Jennifer, The Journal of effective teaching,vol.8.No,2.2008.(pp.61-76). New York: Niagara University

Kallahi, Elanneri.2008 Area of Problem inWriting Recount Text.JurnalPenddikanInovatif,jilid 4,No.1,September 2008,(pp.10-13).PalangKaraya

Oshima and Hongue. 1997. Introduction to Academic Writing. Second Edition. White Plains, New York: Longman.

Pardiyono. 2007. PastiBisa! Teaching Genre-Based Writing. Yogyakarta: Andi

Richard, Jack and Rodgers, Theodore. 1982. Method, Aprroach, Design, Procedure. TESOL Quarterly

Slavin, R.2000. Cooperative Learning: Theory, Research, and Practice (Second Edition). London: A Simon \& Schuster.

Siahaan, Sanggam and Shinoda, Kisno. 2008. Generic Text Structure. $1^{\text {st }}$ ed. $\quad$ Yogyakarta: Grahallmu. 